UNIO - EU Law Journal. Vol. 3, No. 2, July 2017, pp 4-19.

®2017 Centre of Studies in European Union Law

School of Law - University of Minho

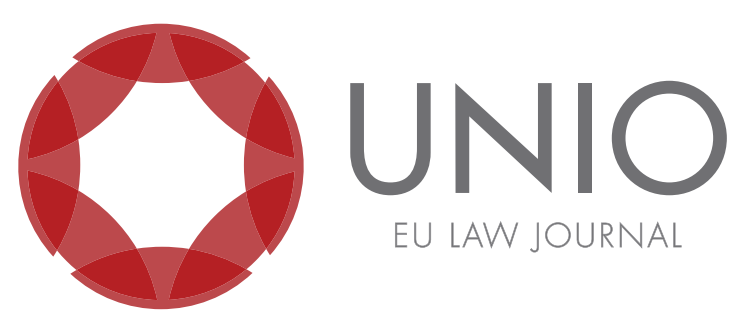

\title{
The asymmetric evolution of the social case-law of the Court of Justice: new challenges in the context of the European pillar of social rights ${ }^{1}$
}

\author{
Luis Jimena Quesada*
}

ABSTRACT: The author highlights the paradoxical evolution of CJEU's case-law in the field of social rights and how in the past, it has played a praetorian role in a context of implied powers and modest EU primary legal provisions whereas now, it is showing clear self-restraint under explicit competences and an evolved EU primary law [including the Charter of Fundamental Rights (CFREU)]. From this perspective, the author proposes the opening of the CJEU to the new framework of the European Pillar of Social Rights, as part of the broader Turin process for the European Social Charter, through positive judicial willingness (by taking into account the synergies between the EU and the Council of Europe - including the case-law from the European Committee of Social Rights).

KEYWORDS: social rights - European Social Charter - Charter of Fundamental Rights of the EU - synergies between EU and the Council of Europe - judicial dialogue and multi-level protection.

\footnotetext{
${ }^{1}$ The present paper has been drafted in the framework of the Research Project "Thematic Network on Constitutional Justice and Judicial Dialogue" (JUDICO) financially supported by the Spanish Ministry of Economy and Competitiveness (Reference: DER2016-81801-REDT; main researcher: Prof. Luis Ignacio Gordillo Pérez) as well as of the Research Group "Human Rights and European Social Charter” (Reference: GIUV2013-148, director: Prof. Carmen Salcedo Beltrán).

* Professor of Constitutional Law (University of Valencia, Spain). Former President of the European Committee of Social Rights (Council of Europe). Member of the Academic Network of the European Social Charter and Social Rights.
} 


\section{Introductory remarks: brief evolution of social rights at an EU normative level and progressive reference to the Council of Europe social rights instruments}

The current challenges in the field of social rights, both at normative and jurisprudential levels within the EU, must be faced in the context of the "European Pillar of Social Rights", which was announced by the President of the European Commission, Jean-Claude Juncker, in his State of the Union address in September 2015 and was formally adopted in April 2017. ${ }^{2}$ In addition, this Pillar must be conceived as part of the most recent social rights developments having emerged in the so-called "Turin process for the European Social Charter", which harmoniously focuses joint efforts of the Council of Europe and the EU to consolidate the European Social Charter as a veritable European pact for the social stability of the Council of Europe's three pillars: social democracy, the welfare state and social rights. ${ }^{3}$ Such harmony should lead to synergies aimed at reaching the best attainable standard for social rights in the EU. ${ }^{4}$

With this in mind, the evolution of social rights at EU normative level has been linked to the realisation of the social policy, whose objectives are currently established in Article 151 TFEU. ${ }^{5}$ This provision, and, in particular, its last paragraph (harmonisation

\footnotetext{
${ }^{2}$ See Communication from the Commission to the European Parliament, the Council, the European Economic and Social Committee and the Committee of Regions establishing a European Pillar of Social Rights, Brussels, 26 April 2017, COM(2007) 250 final. This pillar sets out 20 principles and rights to support fair and well-functioning labour markets and welfare systems. It is designed as a compass for a renewed process of upward convergence towards better working and living conditions within the Union. The pillar is primarily conceived for the euro area but applicable to all EU Member States wishing to be part of it. It was prepared by the Commission, in consultation with stakeholders at all levels, including the Secretary General of the Council of Europe, who recently made public his opinion on the initiative (Strasbourg, 2 December 2016), where he states reminds that "the European Social Charter of the Council of Europe represents an essential component of the continent's architecture of fundamental rights and is therefore seen as the Social Constitution of Europe". The Pillar reaffirms rights that are already present in the EU and international legal acquis, including the European Social Charter The principles and rights enshrined in the Pillar are structured around three categories: equal opportunities and access to the labour market, fair working conditions and social protection and inclusion. The Pillar is presented under two legal forms with identical content: as a Commission Recommendation, and as proposal for a joint proclamation by the European Parliament, the Council and the Commission. On this basis, the Commission will now enter into discussions with the European Parliament and the Council to work towards broad political support and high-level endorsement of the Pillar.

${ }^{3}$ The "Turin process" was launched by the Secretary General of the Council of Europe at the HighLevel Conference on the ESC organised in Turin on 17-18 October 2014 by the Council of Europe in co-operation with the Italian Presidency of the Council of the EU and the Turin municipality. Such process aims at reinforcing the normative system of the ESC within the Council of Europe and in its relationship with the law of the EU. Its key objective is to improve the implementation of social and economic rights at the continental level, in parallel to the civil and political rights guaranteed by the ECHR. See all relevant documents in: http://www.coe.int/en/web/turin-process. ${ }^{4}$ Social rights are also a EU priority for cooperation with the Council of Europe in 2016-2017 by "reinforcing regular dialogue and cooperation with the Council of Europe on the interaction between the European Social Charter and the laws and policies of the EU" (priorities adopted by the Council of the EU on 18 January 2016).

${ }^{5}$ Article 151 TFEU: "The Union and the Member States, having in mind fundamental social rights such as those set out in the European Social Charter signed at Turin on 18 October 1961 and in the 1989 Community Charter of the Fundamental Social Rights of Workers, shall have as their objectives the promotion of employment, improved living and working conditions, so as to make possible their harmonisation while the improvement is being maintained, proper social protection, dialogue between management and labour, the development of buman resources with a
} 
of social systems), has its precedent in the opening provision of Chapter 1 ("Social Provisions") of Title III ("Social Policy") of the Treaty establishing the European Economic Community (TEEC), i.e. Article $117 .{ }^{6}$

In truth, the 1957 TEEC contained few provisions on social policy, which were conceived closely related to two important goals: free competition and worker mobility. In this regard, it has been noted that economic integration was the primary objective of the EEC and its predecessor, the European Coal and Steel Community (ECSC), and the founding Treaties reflected this. ${ }^{7}$ In this sense, even the Treaties establishing the ECSC in 1951 and the European Atomic Energy Community (EAEC) in 1957, emphasized social policy more than the Treaty of Rome did. This is by virtue of the fact that they referred to specific industries (coal, steel, nuclear energy) and the ECSC and EAEC had strong social policy mandates to deal with the employment and health effects of these rapidly changing industries. The ECSC had funds to deal with redundant workers, and the EAEC was empowered to set health and safety standards.

Then, the adoption of the Single European Act (SEA) in 1986 gave a new impetus to several areas of social policy, especially in the working environment (as regards the health and safety of workers) and in the social dialogue (new Articles $118 a$ and $118 b$ TEEC). The SEA also introduced in its Preamble, the first reference to the 1961 European Social Charter in the founding Treaties. ${ }^{8}$ This reference to the main Social Rights Treaty of the Council of Europe acquired binding value with the 1997 Amsterdam Treaty, through its inclusion in the former Article 117 TEEC, which became Article 136 TEC. The content of the latter, through the 2009 Lisbon Treaty, has remained identical in Article 151 TFEU (with the exception of the updated notions of "Union" - instead of "Community" - and "internal market" - instead of "common market"). ${ }^{9}$

Indeed, social progress has been introduced asymmetrically (according to the

view to lasting high employment and the combating of exclusion. To this end the Union and the Member States shall implement measures which take account of the diverse forms of national practices, in particular in the field of contractual relations, and the need to maintain the competitiveness of the Union economy". They believe that such a development will ensue not only from the functioning of the internal market, which will favour the harmonisation of social systems, but also from the procedures provided for in the Treaties and from the approximation of provisions laid down by law, regulation or administrative action".

${ }^{6}$ Article 117 TEEC: "Member States hereby agree upon the necessity to promote improvement of the living and working conditions of labour so as to permit the equalisation of such conditions in an upward direction. They consider that such a development will result not only from the functioning of the Common Market which will favour the harmonisation of social systems, but also from the procedures provided for under this Treaty and from the approximation of legislative and administrative provisions".

${ }^{7}$ K.M. Anderson, Social Policy in the European Union, London, Palgrave Macmillan, 2015, 52-54.

${ }^{8}$ According to the Preamble of the SEA, Member States were "determined to promote democracy on the basis of the fundamental rights recognized in the constitutions and laws of the Member States, in the Convention for the Protection of Human Rights and Fundamental Freedoms and the European Social Charter, notably freedom, equality and social justice".

9 In particular, Article 151 TFEU explicitly mentions "the European Social Charter signed at Turin on 18 October 1961" (together with the 1989 Community Charter of the Fundamental Social Rights of Workers). In parallel, in the Preamble of TEU Member States confirm "their attachment to fundamental social rights as defined in the European Social Charter signed at Turin on 18 October 1961 and in the 1989 Community Charter of the Fundamental Social Rights of Workers". From a formal point of view, the contribution of the Lisbon Treaty to the social policy seems merely terminological. Indeed, apart from including the area of "social policy" in the scope of "shared competence between the Union and the Member States", the Lisbon Treaty states that the heading of Title XI of "social policy, education, vocational training and youth" (old numbering of the Treaty establishing the European Community, TEC) shall be replaced by the heading "social policy" with new renumbering (Title X) in TFEU. 
dynamic of the Europe of different speeds) in EU Primary Law. Thus, in 1989, the United Kingdom was the only one of the then twelve Member Countries of the Union that did not sign the Community Charter of the Fundamental Social Rights of Workers, even though this was conceived as a mere policy document with no compulsory value. In 1992, it was also necessary to include the nucleus of social policy as a Protocol attached to the Maastricht Treaty to make an opting out clause possible, once again for the United Kingdom. For their part, the 1997 Amsterdam Treaty improved the extent of the anti-discriminatory clause (new Article 13 TEC), while the 2001 Nice Treaty created the new Social Protection Committee and tried to better implement the "open method of co-ordination", compensating the achievement of the market with the protection of social rights. Finally, the 2009 Lisbon Treaty gave binding effect to the Charter of Fundamental Rights (CFREU) [new Article 6(1) TEU] by allowing initial confusing opt-out clauses by Poland and the United Kingdom and later on, by the Czech Republic. ${ }^{10}$ Unfortunately, the European social model has, once again, been challenged by the United Kingdom as a part of the "Brexit" vote. "11

\section{Social rights protection through the CJEU's praetorian case- law}

In theory, it might be argued that social rights were capable of benefiting from the initial CJEU's praetorian case-law according to which, without a written legal basis, individual rights "arise not only where they are expressly granted by the Treaty" and "independently of the legislation of Member States", since these rights "become part of their legal heritage" (Judgment of 5 February 1963, Van Gend \& Loos, case 26/62). Otherwise said, social rights should be included among the "fundamental rights enshrined in the general principles of Community law and protected by the Court" (Judgment of 12 November 1969, Stauder, Case 29/69), as well as in the; "fundamental rights recognized and protected by the Constitutions" of Member States and; "similarly, international treaties for the protection of human rights on which the Member States have collaborated or of which they are signatories, can supply guidelines which should be followed within the framework of Community law" (Judgment of 14 May 1974, Nold, Case 4/73).

This theoretical approach seemed to be confirmed in Defrenne III (Judgment of 15 June 1978, Case 149/77) when the Court held that it "has repeatedly stated that respect for

\footnotetext{
${ }^{10}$ See Protocol No. 30 appended to the treaties and concerning the application of the EU Charter to Poland and the United Kingdom (which restricts its interpretation by the Court of Justice and the domestic courts of these two countries, in particular concerning the rights on "Solidarity") as well as Protocol attached to the Presidency Conclusions of the European Council of 29-30 October 2009 (Protocol on the application of the Charter of Fundamental Rights of the European Union to the Czech Republic implying the amendment of Protocol No. 30).

${ }^{11}$ See the British Government's official "Brexit White Paper" (under the title The United Kingdom's exit from and new partnership with the European Union, presented to Parliament by the Prime Minister Theresa May, February 2017), in particular chapter 2 ("Taking control of our own laws": "We will take control of our own affairs, as those who voted in their millions to leave the EU demanded we must, and bring an end to the jurisdiction in the UK of the Court of Justice of the European Union", p. 13) and chapter 7 ("Protecting workers' rights": "UK employment law already goes further than many of the standards set out in EU legislation and this Government will protect and enhance the rights people have at work", p. 31). On the other hand, paragraph 2 of the Judgement given on 24 January 2017 by the Supreme Court of the UK summarizes the domestic procedure leading to the Brexit vote and the complex procedure of withdrawal under Article 50 TFEU (see https://www.supremecourt.uk/news/article-50-brexitappeal.html, visited on 8 February 2017).
} 
fundamental personal human rights is one of the general principles of Community law, the observance of which it has a duty to ensure" and added in relation to Article 119 TEEC that "there can be no doubt that the elimination of discrimination based on sex forms part of those fundamental rights. Moreover, the same concepts are recognized by the European Social Charter of 18 October 1961 and by Convention No. 111 of the International Labour Organization of 25 June 1958 concerning discrimination in respect of employment and occupation". However, the CJEU refused to consider that, in light of Article 119 "Community law contains any general principle probibiting discrimination based on sex as regards the conditions of employment and working conditions of men and women" and, therefore, there was "no rule of the Community law probibiting discrimination between men and women in the matter of working conditions other than the requirement as to pay referred to in Article 119 of the Treaty".

From this perspective, the CJEU's praetorian case-law could be relativised in the field of social rights, insofar as it was clearly formalist. Such formalism was confirmed in Kalanke in $1995 .{ }^{12}$ In this context, the 1997 Amsterdam Treaty (Article 141 TEC) added two other paragraphs on legislative procedure and positive measures which also practically coincide with current paragraphs 3 and 4 of Article 157 TFEU after the entry into force of the Treaty of Lisbon ${ }^{13}$ on December $1^{\text {st }} 2009$. In other words, the evolved gender perspective was a novelty introduced by the Amsterdam Treaty to provide a specific legal basis in the European Treaties in this field, which also aimed at overcoming the restrictive approach established by the CJEU in the Kalanke case, which started to be reviewed in the Marschall case concerning a provision similar to that in Kalanke but, containing a "saving clause". ${ }^{14}$

Before the Kalanke case, the case-law of the CJEU was basically predicated on two important legal acts adopted on the basis of Article 119 TEEC: Council Directive 75/117/EEC of 10 February 1975 on the approximation of the laws of the Member States relating to the application of the principle of equal pay for men and women as well as Council Directive 76/207/EEC of 9 February 1976, on the implementation of the principle of equal treatment for men and women as regards access to employment, vocational training and promotion, and working conditions. Both Directives ${ }^{15}$ were

\footnotetext{
${ }^{12}$ CJEU, Judgment of 17 October 1995, Case C-450/93, Kalanke: "Article 2(1) and (4) of Council Directive 76/207/EEC of 9 February 1976 on the implementation of the principle of equal treatment for men and women as regards access to employment, vocational training and promotion, and working conditions precludes national rules such as those in the present case which, where candidates of different sexes shortlisted for promotion are equally qualified, automatically give priority to women in sectors where they are underrepresented, under-representation being deemed to exist when women do not make up at least half of the staff in the individual pay brackets in the relevant personnel group or in the function levels provided for in the organization chart".

${ }^{13}$ See also Protocol (No. 33) concerning Article 157 TFEU

${ }^{14}$ CJEU, Judgment of 11 November 1997, Case C-409/95, Marschall: "A national rule which, in a case where there are fewer women than men at the level of the relevant post in a sector of the public service and both female and male candidates for the post are equally qualified in terms of their suitability, competence and professional performance, requires that priority be given to the promotion of female candidates unless reasons specific to an individual male candidate tilt the balance in his favour is not precluded by Article 2(1) and (4) of Council Directive 76/207/ EEC of 9 February 1976, on the implementation of the principle of equal treatment for men and women as regards access to employment, vocational training and promotion, and working conditions, provided that: in each individual case the rule provides for male candidates who are equally as qualified as the female candidates a guarantee that the candidatures will be the subject of an objective assessment which will take account of all criteria specific to the candidates and will override the priority accorded to female candidates where one or more of those criteria tilts the balance in favour of the male candidate, and such criteria are not such as to discriminate against the female candidates".

${ }^{15}$ A connecting legal act is Council Directive 79/7/EEC of 19 December 1978 on the progressive implementation of the principle of equal treatment for men and women in matters of social security. In this respect, see CJEU, Judgment of 19 October 1995, Case C-137/94, Richardson:
} 
then repealed and updated by Directive 2006/54/EC. ${ }^{16}$

In conclusion, the CJEU's praetorian case-law concerning EU Primary Law has been developed when having an explicit legal basis. ${ }^{17}$ For example, the CJEU already held in Defrenne II Judgment of 8 April 1976, Case-43/75, where the application of the principle of equal pay for women and women set out in Article 119 TEEC was at stake), that Article 119 TEEC was of such a character as to have not only vertical effect (enforceable not merely between individuals and public authorities), but also a horizontal one (between individuals, Drittwirkung approach), ${ }^{18}$ since; "the probibition on discrimination between men and women applies not only to the action of public authorities, but also extends to all agreements which are intended to regulate paid labour collectively, as well as to contracts between individuals". ${ }^{19}$

\section{Consolidation of classic social case-law under EU secondary law}

The CJEU's classical social case-law has obviously been consolidated by interpreting a wide range of secondary legal provisions, aimed at preventing discriminatory conduct. Thus, EU institutions have adopted several Directives to implement the principle of equal treatment through the prohibition of gender-based discrimination (Gender Equality Directive No 2006/54/EC), and Racial Discrimination (Racial Equality Directive No. 2000/43/EC), as well as a discrimination based on age, disability, religion and belief and sexual orientation (Employment Equality Directive No. 2000/78/EC).

European secondary law has also been developed in the field of safety and health at work on the explicit basis of Article 118a TEEC (introduced in the primary law through the SEA), to which Article 153 TFEU corresponds. This is the case and objective of Council Directive 92/85/EEC of 19 October 1992, on the introduction of measures to encourage improvements in the safety and health at work of pregnant workers and workers who have recently given birth or are breastfeeding. ${ }^{20}$

Moreover, the EU has encouraged the collaboration of the Member States with the social partners in order to continue to address the problem of the continuing gender-based wage differentials and marked gender segregation on the labour market by means of flexible working time arrangements, which enable both men and women to combine family and work commitments more successfully. In this sense, part-time work constitutes a kind of a pilot situation in order to verify, as foreseen in Article 157(2)

\footnotetext{
"Article 7(l)(a) of Directive 79/7 does not allow a Member State which, pursuant to that provision, has set the pensionable age for women at 60 years and for men at 65 years also to provide that women are be exempt from prescription charges at the age of 60 and men only at the age of 65".

${ }^{16}$ Directive 2006/54/EC of the European Parliament and of the Council of 5 July 2006 on the implementation of the principle of equal opportunities and equal treatment of men and women in matters of employment and occupation.

${ }^{17}$ In relation to pay, in its Judgment of 13 September 2007 (Case C 307/0, Del Cerro Alonso), the CJEU pointed out that the principle of non-discrimination cannot be interpreted restrictively.

${ }^{18}$ See M. De Mol, "The Novel Approach of the CJEU on the Horizontal Direct Effect of the EU Principle of Non-Discrimination: (Unbridled) Expansionism of EU Law", Maastricht Journal of European and Comparative Law, No. 18 (2011), 109-135: the author focus on the "sensitive issue" of the application of the EU principle of non-discrimination in private disputes (especially, Mangold, C-144/04, Judgment of 22 November 2005, and Kücükedeveci, C-555/07, Judgment of 19 January 2010). ${ }_{19}$ Paragraph 39.

${ }^{20}$ See Case C 460/06, Paquay, Judgment of 11 October 2007, paragraph 27, and Case C-232/09, Danosa, Judgment of 11 November 2010, paragraph 58.
} 
TFEU not only the specific "principle of equal pay for equal work or work of equal value" and, as a result, the combat against the gender pay gap, but also a broader framework ensuring "the application of the principle of equal opportunities and equal treatment of men and women in matters of employment and occupation".

From this perspective, the CJEU's case-law has dealt with specific controversies concerning the interpretation and application of the European Framework. Agreement on part-time work concluded by UNICE, CEEP and the ETUC on 6 June 1997.21 The CJEU has also considered in breach of EU law the legislation of a Member State which requires a proportionally greater contribution period from part-time workers, the majority of whom are women, than from full-time workers for the former to qualify, if appropriate, for a contributory retirement pension in an amount reduced in proportion to the part-time nature of their work. ${ }^{22}$

Obviously, EU secondary law has been capable of further developments in parallel to the extension of the "integration dynamics" to the social areas through the different "reforms of deepening" of the founding Treaties. Nevertheless, those Treaties left a partial vacuum in terms of social policy because goals were not matched with effective instruments ${ }^{23}$ and this deficit has not been fully remedied yet. Indeed, in spite of the explicit distribution of competences between the EU and Member States through the Lisbon Treaty, a certain degree of ambiguity still appears when facing the concrete delimitation between European and National parameters to achieve the transversal social policy, insofar as the distinction between objective, competence and other related notions remains complex. ${ }^{24}$

Furthermore, the entry into force of the Lisbon Treaty took place in the context of the economic crisis, ${ }^{25}$ what has even weakened those social policy instruments ${ }^{26}$ further, since the development of such policy has not been consolidated in accordance with "the procedures provided for in the Treaties", but following new controversial procedures under the dynamics of the Troika. In addition, the economic crisis has amplified the importance of the $\mathrm{OMC}$, which constitutes a procedure of producing EU soft-law

\footnotetext{
${ }^{21}$ Annexed to Council Directive 97/81/EC of 15 December 1997 (amended by Council Directive 98/23/EC of 7 April 1998). Among others, see Judgments of 5 November 2014 (Österreichischer Gewerkschaftsbund, Case-C476/12), 19 September 2013, (Hliddal, Joined Cases C 216/12 and C 217/129), 8 November 2012 (Heimann and Toltschin, Joined cases C-229/11 and C-230/11), 10 April 2010 (Zentralbetriebsrat der Landeskrankenhäuser Tirols, C 486/08), 7 September 2004 (Commission v Belgium, Case C-469/02), 23 October 2003 (Schönheit and Becker, C 4/02 and C 5/02) and 9 September 1999 (Krüger, C 281/97).

${ }^{22}$ In particular, in Judgment of 22 November 2012, Elbal Moreno, Case C-285/11, the CJEU concluded that there was an indirect discrimination on grounds of sex, since the national measure at issue, albeit formulated in neutral terms, worked to the disadvantage of far more women than men. According to the CJEU: "legislation such as that at issue in the main proceedings works to the disadvantage of part-time workers, such as Ms Elbal Moreno, who have worked part-time for a long time, since, in practice, such legislation excludes those workers from any possibility of obtaining a retirement pension because of the method used to calculate the requisite contribution period" (paragraph 30). It was an indisputable statistical fact that legislation such as that at issue affected women far more than men, given that, in Spain, at least 80\% of part-time workers were women.

${ }^{23}$ K.M. Anderson, Social policy..., 52-54.

${ }^{24}$ K. Lörcher: "Social Competences", in The Lisbon Treaty and Social Europe, I. Schöman/K. Lörcher/N. Bruun (eds), (Oxford: Hart Publishing, 2012), 165.

${ }^{25}$ See more extensively L. Jimena Quesada, Social Rights and Policies in the European Union: New Challenges in a Context of Economic Crisis, (Valencia: Tirant lo Blanch, 2016).

${ }^{26}$ See J.I. García Ninet (dir), El impacto de la gran crisis mundial sobre el Derecho del Trabajo y de la Seguridad Social. Su incidencia en España, Europa y Brasil, 2008-2014, (Barcelona: Ariel, 2014)
} 
which does not lead to binding EU legal acts, but just requires Member States to spread best practices and achieve greater convergence in the social field. ${ }^{27}$ The EP had alerted, even before the crisis, on the abusive use of soft-law instruments. ${ }^{28}$

As a result of this, the new scenario has also weakened the role of the CJEU and its case-law in the field of social rights. Consequently, one of the main challenges in this field is, from the CJEU's case-law perspective, to provide the national courts with more elements to give full effect to social rights by taking into account the potential tools which are already foreseen in EU primary law (for example, the "borizontal social clause" 29 - Article 9 TFEU $^{30}$ - and, of course, the social dimension of the EU citizenship Article 18, 20 and $21 \mathrm{TFEU}^{31}$-, without forgetting the CFREU), in conjunction with a broader social Europe approach (in the spirit of the Turin Process for the European Social Charter).

\section{Paradoxical CJEU's self-restraint under the evolved EU primary law}

In the founding Treaties, Community action was not supported by any explicit competence in the social fields. For this reason, the secondary legislation on social matters adopted within the original European Communities was based on the doctrine of 'implied powers' deriving from Article 235 TEEC (then Article 308 TEC and now the

${ }^{27}$ D. Trubek, "Hard Law and Soft Law in the Construction of Social Europe: The Role of the Open Method of Co-ordination", European Law Journal, No. 11(3) (2005), 343-364. See also L. López Guerra, "Soft Law y sus efectos en el ámbito del Derecho europeo de los derechos humanos", in Teoría y Derecho: revista de pensamiento jurídico, No. 11, 2012, 150-167.

${ }^{28}$ See European Parliament resolution of 4 September 2007 on institutional and legal implications of the use of 'soft law' instruments (2007/2028(INI)): “(...) 18. Reiterates the importance of Parliament's participating, as the main representative of the interests of EU citizens, in all decision-making processes, in order to help reduce their current mistrust in European integration and values; 19. Stresses that the expression of soft law, as well as its invocation, should be avoided at all times in any official documents of the European institutions".

${ }^{29}$ P. Vielle, "How the Horizontal Social Clause can be made to Work: The Lessons of Gender Mainstreaming", in The Lisbon Treaty and ... 105. According to this author, there will be numerous and regular opportunities to invoke the new horizontal social clause in the national courts and the CJEU in order to reiterate the social aims of the Treaty, including on those occasions when economic freedoms enshrined in this same Treaty are subject to examination.

${ }^{30}$ Article 9 TFEU: "In defining and implementing its policies and activities, the Union shall take into account requirements linked to the promotion of a bigh level of employment, the guarantee of adequate social protection, the fight against social exclusion, and a high level of education, training and protection of human health".

31 See G.C. Korteweg, Linking EU citizenship and social rights: 'real link' or illusion? A research of the case law of the Court of Justice on EU citizens' access to social rights, Master Thesis European Law, Utrecht University, April 2015: the author analyses the contribution of the CJEU's case-law on EU citizens claiming social rights to the development of the concept of EU citizenship. The concept of EU citizenship laid down in Articles 20 and 21 TFEU is interpreted in conjunction with the equal treatment principle laid down in Article 18 TFEU. He suggests that the case law of the Court contributed significantly to EU solidarity and assures a degree of social protection for all EU citizens. However, in many recent cases, such as Brey (Case C-140/12, 19 September 2013) and Dano (Case C-333/13, 11 November 2014), which are defining the boundaries of EU citizenship, it has become clear that EU citizens are still subject to certain limitations and conditions. In particular, on the tensions between international market principles (in health care) and the social rights of the citizens of the Union, under the balancing role of the CJEU, see K. Lenaerts \& T. Heremans, "Contours of a European social union in the case-law of the European Court of Justice”, in European Constitutional Law Review, vol. 2, n. 1 (Feb. 2006), 101-115. See also A. Silveira \& C. McKenny Engström, “The emerging culture of EU citizenship as 'citizenship of rights' and the legal nature of the EU polity”, in UNIO - EU Law Journal, vol. 2, n. 2 (2016), 140-154. 
so-called 'flexibility clause' of Article 352 TFEU), with the aim of harmonising the laws of Member States concerning the internal market (ex Article 100 TEEC, then Article 94 TEC, now Article 115 TFEU). ${ }^{32}$ Such legal basis implied putting into practice the unanimity rule.

Later on, the Single European Act conferred explicit powers to European institutions by moving from unanimity to qualified majority rule in relation to the working environment, as regards the health and safety of workers (Article 118, a TEEC), what coincides with the current Article 153(1), $b$ TFEU. Then, the Maastricht Treaty 1992 extended (only through the Agreement appended to Protocol on Social Policy, with the opt-out from the UK) qualified majority voting to several areas: working conditions [Article 153(1), $b$ TFEU and Article 31 CFREU], the information and consultation of workers [Article 153(1), $e$ TFEU and Article 27 CFREU], equality between men and women with regard to labour market opportunities and treatment at work [Article 153(1), $i$ TFEU and Article 23 CFREU], and the integration of persons excluded from the labour market [Article 153(1), $b$ TFEU].

However, that Protocol on Social Policy incorporated to the Maastricht Treaty kept the unanimity rule for other areas, which include; social security and social protection of workers [Article 153(1), c TFEU and Article 34 CFREU]; protection of workers where their employment contract is terminated [Article 153(1), $d$ TFEU and

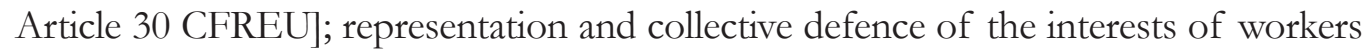
and employers [Article 153(1), $f$ TFEU]; conditions of employment for third-country nationals legally residing in Community territory [Articles 153(2), $g$ and 179(2), $b$ TFEU and Article 15 CFREU] and financial contributions for the promotion of employment and job-creation. On the other hand, that Protocol did not apply to pay, the right of association, the right to strike or the right to impose lock-outs. Similarly, Article 153(1) TFEU keeps such exclusion.

The Amsterdam Treaty incorporated that Protocol on Social Policy to the provisions of the TEC (Article 137). The new version of Article 137 TEC adopted by the Nice Treaty in 2001 added two other social fields; the combating of social exclusion (paragraph 1.j) and the modernisation of social protection systems (paragraph 1.k), which also exactly coincide (like the whole list) with the same paragraphs in the current Article 153 (1) TFEU. Apart from this, both the Nice Treaty 2001 and the Lisbon Treaty 2009 have kept the unanimity rule (established in the Social Protocol to the Maastricht Treaty and in the Amsterdam Treaty) in relation to i) social security and social protection of workers; ii) protection of workers where their employment contract is terminated; iii) representation and collective defence of the interests of workers and employers and $i v$ ) conditions of employment for third-country nationals legally residing in Union territory. From this perspective, the main qualitative difference between the Lisbon Treaty and the previous revisions (mainly, the Amsterdam Treaty and the Nice Treaty) is that the TFEU has extended the ordinary legislative procedure (former co-decision procedure) to those social fields. ${ }^{33}$

In any case, putting into practice the Union action in these fields is very complex (including the use of the adjective social), ${ }^{34}$ not only because of the existence of

\footnotetext{
${ }^{32}$ See, for example, Council Directive 75/129/EEC of 17 February 1975 on the approximation of the laws of the Member States relating to collective redundancies.

${ }^{33}$ Article 153.2 TFEU states that "To this end, the European Parliament and the Council...", while Article 137 TEC (Amsterdam and Nice consolidated versions) said that "To this end, the Council...".

${ }^{34}$ In EU language "social" also relates to employment policy, working conditions and labour law.
} 
potential and different procedures and actors foreseen in Article 153 TFEU (Member States, European institutions and bodies as well as European social partners), but also because the boundary problems concerning the distributions of competences are evident in relation to social policy. ${ }^{35}$

As is well known, the Lisbon Strategy (agreed in the Lisbon European Council in March 2000 and targeted the year 2010) included, in the framework of a comprehensive approach, the promotion of the inclusion of people who suffer from poverty or social exclusion. Similarly, the EU 2020 Strategy (which came into effect on 17 June 2010 as the follow-up strategy to the Lisbon Strategy) has outlined, among the five strategic headline targets, two targets which are directly related to the labour market and social policies, namely; that the EU is to raise employment rates among men and women to 75 per cent and reduce the number of persons at risk of poverty and social exclusion by 20 million by the year 2020 .

In this last regard, while Article 153(1), $j$, TFEU includes "the combating of social exclusion", Article 153(2) TFEU does not even mention this field among the potential actions and procedures to be undertaken. In other words, paragraph 2 of Article 153 TFEU does not paradoxically empower the EU institutions to take any measures towards the end established in its paragraph 1. How to compensate this intentional omission? On the one hand, it is clear that in compliance with the principle of subsidiarity, Member States' local, regional and national authorities have a primary and major role to play in adopting initiatives to combat poverty and social exclusion. On the other hand, it is also evident that the combating of exclusion is not only one of the Union's social objectives according to Article 151 TFEU (in conjunction with Article 153 TFEU), but also one of the Union's main and general objectives set forth in Article 3 TEU, which refers to; "a highly competitive social market economy, aiming at full employment and social progress" by adding that the EU "shall combat social exclusion and discrimination, and shall promote social justice and protection, (...) solidarity between generations (...)" (paragraph 3). ${ }^{36}$

As a result, Article 34 CFREU must also be taken into account by "institutions, bodies, offices and agencies of the Union with due regard for the principle of subsidiarity" and by "Member States" when they are implementing EU law (in accordance with Article 51 CFREU). In particular, paragraph 3 of Article 34 CFREU states that; "in order to combat social exclusion and poverty, the Union recognises and respects the right to social and housing assistance

From this point of view, the adjective "social" may be applied not only to the specific Title X of the TFEU on "Social Policy", but also to Titles IX ("Employment), XII ("Education, Vocational Training, Youth and Sport") and XVIII ("Economic, Social and Territorial Cohesion"). It must also be recalled that, before the Lisbon Treaty, social policy was included into a broader Title on "Social Policy, Education, Vocational Training and Youth" (Title VIII in the Maastricht Treaty and Title XI in both the Amsterdam and the Nice Treaties).

${ }^{35}$ P. Craig, The Lisbon Treaty: Law, Politics, and Treaty Reform, Oxford, Oxford University Press, 2010, 180: "the difficulties in this area are especially marked, since certain aspects of social policy fall within shared competence, although it is not clear which; other aspects appear to fall within the category of supporting, coordinating, and supplementary action, even though they are not within the relevant list, ant there is in addition separate provision for social policy in the category being considered here".

${ }^{36}$ In addition, paragraph 5 of Article 3 TEU states: "In its relations with the wider world, the Union shall uphold and promote its values and interests and contribute to the protection of its citizens. It shall contribute to (...) solidarity and mutual respect among peoples, free and fair trade, eradication of poverty and the protection of buman rights". In the same vein, these general objectives established in Article 3 TEU are closely related to the values referred to in Article 2 TEU: "The Union is founded on the values of respect for buman dignity, freedom, democracy, equality, the rule of law and respect for human rights, including the rights of persons belonging to minorities. These values are common to the Member States in a society in which pluralism, non-discrimination, tolerance, justice, solidarity and equality between women and men prevail'. 
so as to ensure a decent existence for all those who lack sufficient resources, in accordance with the rules laid down by Union law and national laws and practices".

In light of this last consideration, an essential reference must be made to the explanation on Article 34 CFREU, which explicitly refers to Article 13 (the right to social and medical assistance) and Articles 30 (the right to protection against poverty and social exclusion) and 31 (the right to housing) of the 1996 Revised European Social Charter as well as, above all, to Article 153 TFEU, by somehow compensating the aforementioned omission. This Explanation holds: "Paragraph 3 draws on Article 13 of the European Social Charter and Articles 30 and 31 of the revised Social Charter and point 10 of the Community Charter. The Union must respect it in the context of policies based on Article 153 of the Treaty on the Functioning of the European Union".

In this sense, some authors have proposed a "buman-developmental interpretation" of EU Primary Law which, should lead to the systematic promotion of social goals enshrined in the Treaty in connection with the CFREU. Their premise is that the EU is not based solely on objectives, and the notion of values appeared in the European discourse with the conclusion of the Constitutional Treaty, ${ }^{37}$ which was has been "substantially rescued" on these matters by the Lisbon Treaty. ${ }^{38}$ From this perspective, those authors developed an evaluation of the CFREU, looking at the constitutional values underlying the Charter with the purpose of strengthening the social dimension vis-à-vis the conflicting economic objectives. ${ }^{39}$ Nonetheless, these authors seem to be much more in favour of another instrument (instead of EU Law and the CJEU's caselaw): the ECHR, supported by the ECtHR. ${ }^{40}$

In my view, in spite of the self-restraint exercised by the CJEU in some social fields (and, especially, its reluctance to exploit the social rights recognised in the CFREU under the heading of 'solidarity'), the importance of the social case-law from the ECtHR cannot be exaggerated. In the field of combating poverty and social exclusion, without prejudice to several interesting judgments from Strasbourg, ${ }^{41}$ the specific case-law on this topic is being elaborated by the European Committee of Social Rights, precisely under Articles 13, 30 and 31 of the European Social Charter. ${ }^{42}$

Ultimately, the paradoxical evolution of CJEU's case-law in the field of social rights lies in the fact that it played, in the past, a praetorian role in a context of implied

\footnotetext{
${ }^{37}$ See S. Deakin, "The Lisbon Treaty, the Viking and Laval Judgments and the Financial Crisis: In Search of New Foundations for Europe's Social Market Economy", in The Lisbon Treaty and Social Europe, I. Schöman/K. Lörcher/N. Bruun (eds), op.cit., 19.

${ }^{38}$ F. Aldecoa Luzarraga \& M. Guinea Llorente, El rescate sustancial de la Constitución Europea a través del Tratado de Lisboa: la salida del laberinto, Real Instituto Elcano (Working Paper No. 9), Madrid, 2008. See also J. Ziller, "Il Trattato modificativo del 2007: sostanza salvata e forma cambiata del Trattto costituzionale de 2004", Quaderni costituzionali, No. 4 (2007), 875-892.

39 See also C. Peraro, "Right to collective action in cross-border employment contexts: a fundamental social right not yet covered by EU private international law", UNIO - EU Law Journal, Vol. 2, No. 2 (2016), 20-38.

${ }^{40}$ In particular, P. Dorssemont, "Values and Objectives", in The Lisbon Treaty and Social Europe, I. Schöman/K. Lörcher/N. Bruun (eds), op.cit., 45. See also A. Bar Cendón, "La Unión Europea como unión de valores y derechos: teoría y realidad”, in Teoría y Realidad Constitucional, No. 33 (2014), 99-139.

${ }^{41}$ E.g., ECtHR, Winterstein and Others v France, Judgment of 17 October 2013. A contextual analysis of this social case-law from the ECtHR in López Guerra, "La protección de derechos económicos y sociales en el Convenio Europeo de Derechos Humanos", in Tratado sobre Protección de Derechos Sociales, M. Terol Becerra/L. Jimena Quesada (dirs), Valencia, Tirant lo Blanch, 2014, 297-317.

${ }^{42}$ Among others, Decisions on the Merits of 18 February 2009 (Complaint No. 48/2008, ERRC $v$ Bulgaria), of 25 June 2010 (Complaint No. 58/2009, COHRE v Italy) and of 28 June 2011 (Complaint No. 63/2010, COHRE v. France). Cf. ECtHR Budina v Russia, Decision of 18 June 2009.
} 
powers and modest EU primary legal provisions, whereas now, it is showing a clear self-restraint under explicit competences and an evolved EU primary law (including the CFREU). To face such a paradox, a more expansive judicial activism and opening to judicial dialogue may be traced in the sphere of social rights in order to avoid inconsistencies within the EU Charter, and thus with democratic legitimacy. ${ }^{43}$

In real terms, the social case-law from the CJEU has evolved and is undoubtedly valuable. In contrast, it has known a recent restrictive evolution in other fields covered by Article 153 TFEU and the CFREU, such as the workers' right to information and consultation within the undertaking (Article $27 \mathrm{CFREU}$ ) or protection in the event of unjustified dismissal (Article 30 CFREU). Furthermore, these two aspects have been assessed without taking into consideration the European Social Charter (and the interpretation by the European Committee of Social Rights) and, therefore, both have raised the issue of real or potential divergent views between the CJEU and the Committee.

In particular, concerning the right to information and consultation within the undertaking, the recent restricted approach (restriction contrary to the Opinion of Advocate General Cruz Villalón) is illustrated by case C-176/12, Association de médiation sociale, Judgment of 15 January $2014 .{ }^{44}$ By contrast, the same situation was analysed by the Committee under Article 21 of the Revised Social Charter and, also by taking into account EU law (even in the light of the aforementioned judgment of the CJEU, which is explicitly cited), it concluded that there was a breach of such provisions. ${ }^{45}$

In relation to protection in case of termination of employment, in Case C-117/14 (Nisttabur Poclava, Judgment of 5 February 2015) the CJEU decided not to tackle the impact (under EU and external law sources which were explicitly mentioned by the referring domestic court ${ }^{46}$ of the new employment contract to support entrepreneurs

${ }^{43}$ P. Gjortler, "Democratic Legitimacy and the Court of Justice of the European Union", in Democratic Legitimacy in the European Union and Global Governance. Building a European Demos, B. Pérez de las Heras (ed), (London: Palgrave Macmillan, 2017), 180.

44 According to this ruling: "Article 27 of the Charter of Fundamental Rights of the European Union, by itself or in conjunction with the provisions of Directive 2002/14/EC of the European Parliament and of the Council of 11 March 2002 establishing a general framework for informing and consulting employees in the European Community, must be interpreted to the effect that, where a national provision implementing that directive, such as Article L. 1111-3 of the French Labour Code, is incompatible with European Union law, that article of the Charter cannot be invoked in a dispute between individuals in order to disapply that national provision". See also, in the same restrictive direction (concerning Article 20 of the EU Charter), CJEU, Case C-198/13, Julián Hernández, Judgment of 10 July 2014.

${ }^{45}$ See Conclusions 2014, Article 21, France (published in January 2015): "The minimum framework which the Committee has adopted for Article 21 of the Charter is Directive 2002/14/EC of the European Parliament and of the Council of 11 March 2002. In this context, the Committee points out that all categories of worker (all employees holding an employment contract with the company regardless of their status, length of service or place of work.) must be included in the calculation of the number of employees enjoying the right to information and consultation (judgments of the Court of Justice of the European Union, Confédération générale du travail and Others, Case No. C-385/05 of 18 January 2007, and Association de médiation sociale, Case No. C-176/12 of 15 January 2014). It considers therefore that the exclusion, provided for in Article L. 1111-3 of the Code, of workers on state-subsidised contracts from the calculation of companies' staff numbers - a calculation which is necessary to determine the minimum thresholds beyond which staff representative bodies ensuring the information and consultation of workers must be set up - is not in conformity with the Charter".

${ }^{46}$ Including Article 30 CFREU, Directive 1999/70, 1982 ILO Convention No. 158 concerning the Termination of Employment at the Initiative of the Employer and the 1961 European Social Charter 1961 (in relation to the decision of the European Committee of Social Rights of 23 May 2012 on a similar Greek contract, Complaint No. 65/2011, General federation of employees of the national electric power corporation and Confederation of Greek Civil Servants' Trade Unions v. Greece). 
(entailing a one-year probationary period during which the employer might freely terminate the contract without notice or compensation) introduced in Spain by Law 3/2012 of 6 July 2012 on urgent measures for labour market reform to face the economic crisis. For the CJEU, in spite of Article 30 CFREU, the situation at issue paradoxically did not fall within the scope of EU law.

\section{Final thoughts: the necessary opening of the CJEU to the new framework of the European Pillar of Social Rights}

The last two rulings from the CJEU (the Association de médiation sociale and Nisttabuz Poclava cases) reveal a restrictive position in relation to the CFREU (in particular to the workers' right to information and consultation within the undertaking - Article 27 - and to the protection in the event of unjustified dismissal - Article 30) and, at the same time, a reluctant approach to the more favourable standards in these fields under the European Social Charter and the interpretation from the European Committee of Social Rights. By contrast, the ECtHR has been more sensitive to establishing a judicial dialogue with the Committee. ${ }^{47}$

With this in mind, the consistency with these Council of Europe standards also demonstrates a controversial judicial strategy from the domestic courts which have submitted an unnecessary request for a preliminary ruling (since both national courts were entitled -and had- to exercise the conventionality control, by directly applying the Social Charter and the Committee's case-law $)^{48}$ and, in parallel, have made emerged contradictory solutions putting the credibility of the whole human rights European system at risk.

My constructive criticism leads to a clear conclusion, which is that the necessary opening of the CJEU to the new framework of the European Pillar of Social Rights, as part of the broader 'Turin process for the European Social Charter', through positive judicial willingness (by taking into account the synergies between the EU and the Council of Europe - including the case-law from the European Committee of Social Rights). Indeed, the adjective "social" was explicitly added to the definition of the "European economic model' late in the primary law of the EU, particularly in the Lisbon Treaty, but it gave legally binding force to the CFREU, whose catalogue of social rights (especially those under the heading "Solidarity") have been precisely based on the European Social Charter of the Council of Europe. The latter, which reflects to a large extent the "European social modep', has been ratified by all Member States of the EU (in most cases even before EU membership).

From this point of view, it is evident that normative interactions between the Social Charter and EU law are explicit. Firstly, the references to the Social Charter have been confirmed by the current sources of EU primary law after the entry into force of the Treaty of Lisbon, ${ }^{49}$ including the CFREU (see the Appended Explanations).

\footnotetext{
${ }^{47}$ For an illustration, see ECtHR, Sorensen and Rasmussen v Denmark, Judgment of 11 January 2006, as well as Demir and Baykara v Turkey, Judgment of 12 November 2008.

${ }^{48}$ See C. Salcedo Beltrán, "La aplicabilidad directa de la Carta Social Europea por los órganos judiciales", Trabajo y Derecho, No. 13, enero 2016, 27-52. See also G. Guiglia, "The importance of the European Social Charter in the Italian Legal System: in pursuit of a stronger protection of social rights in a normative and internationally integrated system", in European Social Charter and the challenges of the XXI century. La Charte Sociale Européenne et les défis du XXIe siècle, M. D'Amico/G. Guiglia (eds), Napoli, Edizioni Scientifiche Italiane, 2014, in particular, 85-87.

${ }^{49}$ See TEU (Preamble, \5) as well as TFEU (Article 151).
} 
Secondly, the links between the Social Charter and sources of EU secondary law are also important in both directions as well. ${ }^{50}$ Finally, the Social Charter is also presented in significant non-binding instruments of the EU, precisely related to legal synergies between the Council of Europe and the EU. ${ }^{51}$

With such premises, regarding the establishment of coherent and harmonious relationships between the two normative systems (EU and Council of Europe) ${ }^{52}$ in favour of the harmonization of the social models, it appears essential to positively exploit the "borizontal social clause" (Article 9 TFEU) as well as the social dimension of the CFREU (both at judicial ${ }^{53}$ and non-judicial levels) ${ }^{54}$, without forgetting the EU accession to the European Social Charter ${ }^{55}$ as a further step to complete the parallel accession to the ECHR. ${ }^{56}$

However, these normative links appear to be more complex in practice. Actually, in contrast with the Bosphorus doctrine,${ }^{57}$ the European Committee of Social Rights has not accepted a general presumption of compatibility between EU social legislation and

${ }^{50}$ As well known, the Community Charter of the Fundamental Social Rights of Workers (a declaration adopted in 1989 by eleven Heads of State and Government of the European Economic Community) was explicitly inspired by the Charter of 1961. On the basis of this declaration, the community institutions then adopted a series of directives on labour law. On the other hand, the Explanatory Report of the Revised Social Charter makes clear that some of its provisions were inspired by those directives.

${ }^{51}$ I.e. European Parliament Resolution of 27 February 2014 on the situation of fundamental rights in the European Union (2012): "The European Parliament, (...) - having regard to the European Social Charter, as revised in 1996, and the case law of the European Committee of Social Rights, (...)".

${ }^{52}$ See M. Brillat, Le principe de non-discrimination à l'épreuve des rapports entre les droits européens, Institut Universitaire Varenne, Paris, 2015, in particular Part II ("L'indispensable cohérence européenne en matière d'interdiction de toute discrimination"), 219 and ff.

${ }^{53}$ Cf. the restrictive approach which has been recently expressed by the CJEU, among others, in Case C-539/14, Sánchez Morcillo and Abril Garcia, Order of 16 July 2015: "that provision of the Charter [Article 34(3) CFREU] does not guarantee the right to housing, but rather the right to social and housing assistance' in social policies based on Article 153 TFEU' (paragraph 49).

${ }^{54}$ See the Opinion of the Management Board of the FRA on the European Commission's Proposal for a New Multi-Annual Framework (2013-2015) for the Agency: "the new Framework should include social rights explicitly. This would ensure a balance of coverage of the rights listed in the Charter, which take up almost a quarter of this instrument and are of particular relevance to everyone".

55 See O. De Schutter, L'adhésion de l'Union européenne à la Charte sociale européenne. Bruxelles: Université Catholique de Louvain, 8 July 2014, 54 pages (http://www.coe.int/t/dghl/monitoring/ socialcharter/Presentation/PublicationCSEUEODeSchutterJuly2014_en.pdf; visited on 6 August 2014). The report recalls the reasons why the dossier now deserves to be revisited.

${ }^{56}$ Cf. CJEU (Full Court), Opinion 2/13, 18 December 2014: "The agreement on the accession of the EU to the ECHR is not compatible with Article 6(2) TEU or with Protocol (No. 8) relating to Article 6(2) TEU on the accession of the EU to the ECHR". By contrast, as stated in the European Parliament Resolution of 19 May 2010 on the institutional aspects of the accession of the EU to the ECHR [Document of the European Parliament 2009/2241(INI)]: “(...) 30. Notes that accession by the Union to the ECHR signifies the recognition by the EU of the entire system of protection of human rights, as developed and codified in numerous documents and bodies of the Council of Europe; in this sense, accession by the Union to the ECHR constitutes an essential first step which should subsequently be complemented by accession by the Union to, inter alia, the European Social Charter, signed in Turin on 18 October 1961 and revised in Strasbourg on 3 May 1996, which would be consistent with the progress already enshrined in the Charter of Fundamental Rights and in the social legislation of the Union; 31. (...) stresses also the need for the Union to be involved in the work of the Commissioner for Human Rights, the European Committee of Social Rights, (...) and asks to be duly informed of the conclusions and decisions of these bodies;...”.

${ }^{57}$ ECtHR, Bosphorus Hava Yollari Tutizim ve Ticaret Anoniom Sirketi v Ireland, Application No. 45036/98, Judgment of 30 June 2005. 
the Social Charter, ${ }^{58}$ in particular in controversial areas such as organisation of working time ${ }^{59}$ or delocalisation of undertakings and social dumping, ${ }^{60}$ without forgetting anticrisis legislation and austerity measures. ${ }^{61}$

This lack of presumption is very significant, in view of the overlapping membership of the European Union and the Council of Europe. From this point of view, the complexities of synergies are accentuated, since the European Committee of Social Rights is increasingly occupying a place next to the two European Courts (CJEU and the ECtHR ${ }^{62}$ in this area. ${ }^{63}$

Nevertheless, overcoming such complexities depends on a simple human factor, that it to say, to promote a positive judicial willingness in order to exploit the favor libertatis or pro personae clauses (Articles 52(3) and 53 CFREU, Article 53 ECHR or Article 32 of the European Social Charter - Article H of the Revised Charter) through

${ }^{58}$ See further developments in P. Stangos, "Les rapports entre la Charte sociale européenne et le droit de l'Union européenne: le rôle singulier du Comité européen des Droits Sociaux et de sa jurisprudence", in Cabiers de droit européen, No. 49, 2013, 319-393.

${ }^{59}$ E.g. Decision on the merits of 23 June 2010 on Complaint No. 55/2009, Confédération Générale du Travail v France, paragraphs 31-42.

${ }^{60}$ E.g. Decision on admissibility and the merits on Complaint No. 85/2012, Swedish Trade Union Confederation (LO) and Swedish Confederation of Professional Employees (TCO) v Sweden), paragraphs 72-74.

${ }^{61}$ The Court of Luxembourg has conferred an important weight to national parameters (or, more exactly, to state margin of discretion) based on anti-crisis legislation incorporating austerity measures deriving from the operations of the Troika. A recent illustration of this approach is offered by the above mentioned Case C 117/14 (Nisttabur Poclava, Judgment of 5 February 2015), concerning the employment contract of indefinite duration to support entrepreneurs introduced by Law 3/2012 of 6 July 2012 on urgent measures for labour market reform, which amended the employment legislation because of the economic crisis that Spain was undergoing. The CJEU stated that Article 30 CFREU was not stake, since "the fact that the employment contract of indefinite duration to support entrepreneurs may be financed by structural funds is not sufficient, in itself, to support the conclusion that the situation at issue in the main proceedings involves the implementation of EU law for the purposes of Article 51(1) of the Charter" (paragraph 42). In addition, for the CJEU, the external international sources which are invoked by the referring court (including those explicitly mentioned in Article 151 TFEU, such as the European Social Charter) would not have any impact, due to the fact that "the Court has no jurisdiction under Article 267 TFEU to rule on the interpretation of provisions of international law which bind Member States outside the framework of EU law" (paragraph 43). For these reasons, the Court concluded the situation at issue in the main proceedings did not fall within the scope of EU law. The final solution reached in Luxembourg is perhaps not so deceiving if we take into account the fact that, this way, a potential contradiction between the CJEU and the previous decision adopted on 23 May 2012 by the European Committee of Social Rights (Complaint No. 65/2011, General federation of employees of the national electric power corporation and Confederation of Greek Civil Servants' Trade Unions v. Greece) has been avoided. In particular, in its decision, the Committee of Strasbourg declared that the 2010 Greek legislation (imposed by the Troika) allowing dismissal without notice or compensation of employees in an open-ended contract during an initial period of twelve months was incompatible with Article $4 \$ 4$ of the 1961 Social Charter.

${ }^{62}$ From this point of view, in a Decision of 7 May 2013, the ECtHR declared inadmissible the cases of Ioanna Koufaki and ADEDY (Applications No. 57665/12 and 57657/12) v Greece. Relying on Article 1 of Protocol No. 1, the applicants complained of the cuts in wages and pensions resulting from Laws No. $3833 / 2010,3845 / 2010$ and 3847/2010 (the second applicant also alleged violations of Articles $6 \$ 1,8$, 13, 14 and 17 of the ECHR). In spite of the substantial similarities with Complaints No. 76 to 80/2012, the ECtHR reached its decision without referring to the decisions on the merits of the European Committee of Social Rights of 7 December 2012. As a matter of fact, it considered that "the complaint concerning Article 1 of Protocol No. 1 is manifestly ill-founded" (paragraph 49). In addition, with regards to the complaint concerning the other alleged provisions of the ECHR, the Court found nothing in the case file which might disclose "any appearance of a violation of these provisions" (paragraph 50).

${ }^{63}$ See S. Douglas-Scott, "A Tale of Two Courts: Luxembourg, Strasbourg and the Growing European Human Rights Acquis", in Common Market Law Review, No. 43 (2006), 629. 
a sincere judicial dialogue at both horizontal (CJEU, ECtHR and European Committee of Social Rights) and vertical (with National Courts) levels (multi-level protection). ${ }^{64}$

Such mutual inter-action is of central importance to the development of social rights standards in constitutionalising the European Social model. Indeed, strengthening the synergies between the EU and the Council of Europe is, in my view, one of the key elements for the success of the new European Pillar of Social Rights, as part of the broader Turin process for the European Social Charter.

\footnotetext{
${ }^{64}$ F. Valdés Dal-Ré, El constitucionalismo laboral europeo y la protección multinivel de los derechos laborales fundamentales: luces y sombras (Albacete: Bomarzo, 2016). More specifically, the favor libertatis clause of the CFREU has been emphasized has an essential element in connection with the actual enforcement of the judgments of the CJEU in order "to optimize the domestic legal order and, above all, as an essential element to improve the degree of Europeanism of citizenship". B. Tomás Mallén, "La ejecución de sentencias del Tribunal de Justicia como responsabilidad constitucional compartida: luces y sombras", in Teoría y Realidad Constitucional, No. 39 (2017), 481.
} 